\title{
A new type of interpenetration twin of labradorite from East Greenland
}

\author{
EDUARD WENK AND ALFRED GLAUSER
}

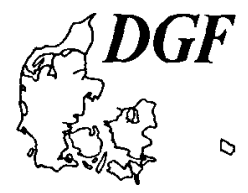

\begin{abstract}
Wenk, E. and Glauser, A.: A new type of interpenetration twin of labradorite from East Greenland. Bull. geol. Soc. Denmark, vol. 35, pp. 25-29, Copenhagen, October, 29th, 1986. https://doi.org/10.37570/bgsd-1986-35-04

Labradorite phenocrysts of basaltic rocks collected from the moraine of Daugaard-Jensen Gletscher in Scoresby Sund, East Greenland, have been studied by U-stage methods. Interpenetrating fourlings after (010) have the axis [001] in common. The (010) planes of the two fourlings form an angle of $38^{\circ} \pm 1^{\circ}$ in the example illustrated. Two rectangular planes of symmetry between the two systems intersect in [001], but are not developed as morphological boundary planes. These symmetry planes bring the twin axes of the Albite, Carlsbad and Albite-Carlsbad laws of one fourling into the position of those of the second four-ling. The same mirror reflection brings the vibration directions $n \alpha, n \beta, n \gamma$ of each individual of the first fourling into the position of corresponding indicatrix axes of an individual of the second fourling. As a sec-ond interpenetration with common [001] but with an angle of $52^{\circ}$ between the planes $(010)$ has been found, we conclude that the coinciding axis [001] is the characteristic feature of this new type of inter-growth.

A geological implication from this study is the proof for the occurrence of basalt in the bed-rock below the ice cap west of Daugaard-Jensen Gletscher, $150 \mathrm{~km}$ north of the northemmost extension of the thick pile of plateau basalts of the Brito-Arctic province along the East Coast of Greenland.
\end{abstract}

E. Wenk and A. Glauser, Mineralogisch-Petrographisches Institut der Universität Basel, Bernoullistrasse 30, Basel, CH-4056, Switzerland. July 8th, 1985.

Rock samples from the northwestern part of Hinks Land, Scoresby Sund, East Greenland, have been investigated. They were collected from the southern moraine of the Daugaard-Jensen Gletscher, and from blocks scattered on the roches moutonnées to the south of the glacier $\left(71^{\circ} 44^{\prime} \mathrm{N} 29^{\circ} 05^{\prime} \mathrm{W}\right)$.

Four samples of porphyritic olivine-bearing basalt and dolerite contained $1 \mathrm{~cm}$ long, well twinned phenocrysts of fresh, homogeneous labradorite which suggested a detailed optical U-stage study. Table 1 contains Euler angles derived from threelings and fourlings with (010) as composition plane. These angles fix the optic orientation with regard to $\mathrm{Z}=[001] \mathrm{Y}=$ pole $(010), \mathrm{X}=$ $\perp[001] /(010)$ and indicate a narrow compositional range of An 63-69 for the phenocrysts (Fig. 1). These data agree with those on labradorite from a Tertiary plateau basalt Gaa 615 found north of the Gaase Gletscher, in the southwestern part of Scoresby Sund (Wenk et al. 1961, Wenk 1961). They are also very similar to the data on labradorites from the recent volcano Surtsey in Iceland (Wenk et al. 1965) and from Lake County, Oregon. As mentioned by Barth (1969), large non-zoned plagioclase crystals An
66-67 are common in basaltic rocks whose normative anorthite content is much more sodic. In this compositional range, the optic determination curves 'high' and 'low' intersect (Burri et al. 1967). Thus there is probably no distinction in optical properties near the composition $2 / 3$ An, $1 / 3 \mathrm{Ab}$. The plagioclases of the matrix of the Daug-samples are more sodic (An 45-60) than the phenocrysts.

Many of the twinned labradorite phenocrysts in the basaltic rocks from the moraine of the Daugaard-Jensen Gletscher are in contact or interpenetrate in a purely accidental way. Only a minority form regular intergrowths, either along crystallographic composition planes (e.g. (001) parallel $(010)$, or more rarely, with a twin relation between the two systems. A model for the last case is shown in Fig. 2. Two fourlings after (010), both of them twinned after the Albite, Carlsbad and Albite-Carlsbad laws, interpenetrate at a low angle, but no regular boundary surface could be seen. The optic orientation of the eight individuals contained in the two fourlings, and their (010) planes were measured on the $U$-stage by both authors independently and were plotted on a large-scale stereographic pro- 
Table 1: Mean Euler angle values of plagioclase threelings and fourlings from Daugaard-Jensen Gletscher, compared with those of known standards.

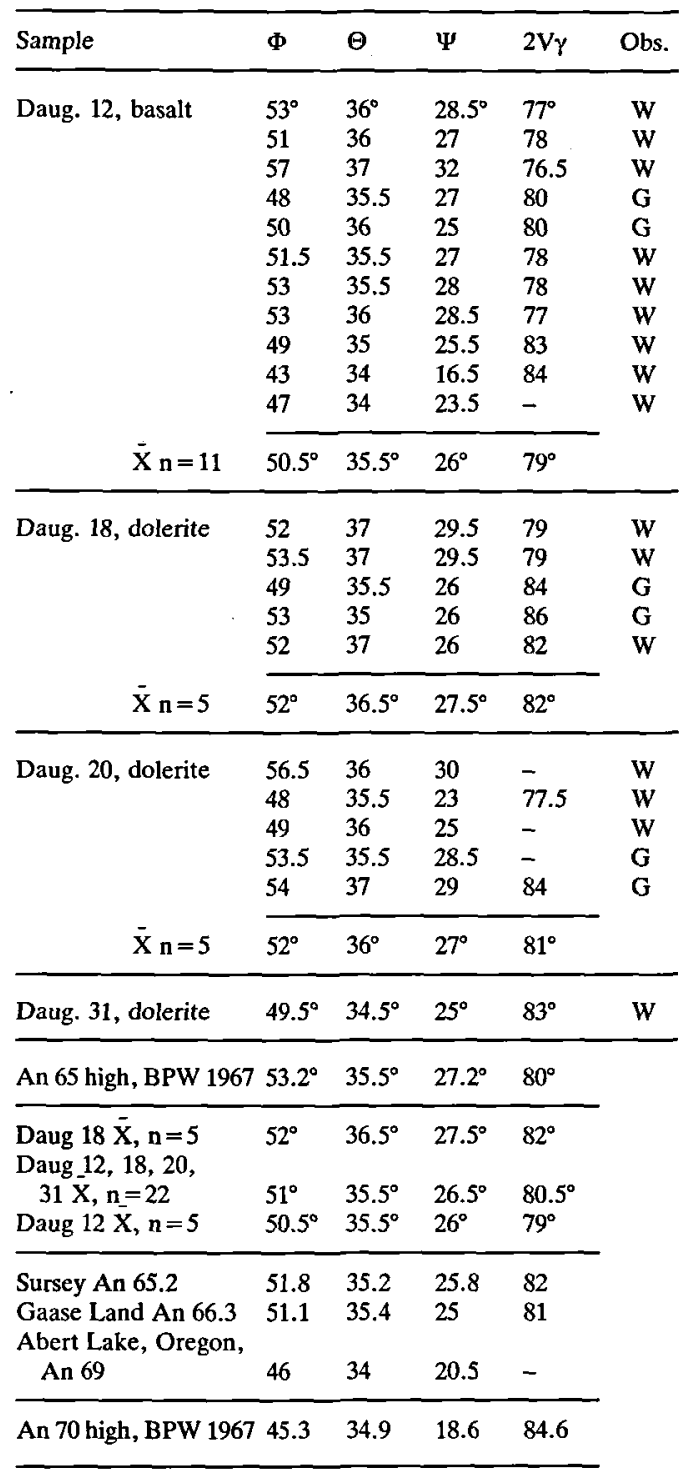

jection $(\mathrm{d}=40 \mathrm{~cm})$. Based on the symmetry of the indicatrices, the twin axes of both fourlings were constructed and the eight sets of Euler angles derived. Both of the operators found that the twin axes [001] of the Carlsbad law of the two intergrown fourlings agree within $1^{\circ}-$ within the margin of error! The (010) planes of the two systems form an angle of $38^{\circ} \pm 1^{\circ}$. Two perpendicular symmetry planes between the interpenetrating fourlings intersect in [001] (see legend of
Fig. 2), but they are not developed as morphological boundary planes.

After having found a second intergrowth of labradorite with common [001] in plateau basalt north of Gaase Fjord, however with an angle of $52^{\circ}$ between the planes $(010)$ of the two systems, we conclude that the coinciding axis [001] is the characteristic feature of this new type of intergrowth. It may be more common in porphyritic basaltic rocks than previously thought, but its presence can only be demonstrated by careful optic analysis of suitable intergrowths. It represents a counterpart to the cross-shaped interpenetrations, described as 'Banater Verwachsung' by Streckeisen (1932) and as 'Baveno-Zwillinge vom Banater Typ' by Burri (1963). To date no stereograms of these intergrowths have been published. A new study of interpenetrations of this type is in progress and shows that the zone axis [100] is common to all individuals and that (010) of one system coincides with (001) of the other system. Boundary surfaces oblique to these directions are rarely developed as crystallographical planes. But we observed in most of these cases that (021) of an individual of one system agrees with ( $0 \overline{2} 1)$ of a contacting individual of the second system.

Our investigation also touches on a problem of Greenland geology, viz. the extent of the plateau basalts of the Brito-Arctic province, northwest of the well-known occurrences along the East Coast. Daugaard-Jensen Gletscher is the most active glacier in Scoresby Sund, and the erratics described here give information on the bed-rock present below the ice cap. As shown by the Geological Map of Greenland 1:500000, Sheet 12, Scoresby Sund, 1984, Charcot Land as well as Hinks Land border the Daugaard-Jensen Gletscher to the north and south and consist of metamorphic and granitoid rocks. Even in the nunataks of that area no Neogene flood basalts have been located. The northwesternmost extension of the thick pile of plateau basalt, covering roughly one million square kilometers in the area south of Scoresby Sund, has been traced to the western part of Paul Stern Land, $150 \mathrm{~km}$ south of the Daugaard-Jensen Gletscher. However, a swarm of NNE trending subvertical dolerite dikes, which cut the crystalline basement and the overlying lowermost plateau basalts of Gaase Land in southwestern Scoresby Sund, can be followed as far north as the innermost parts of Nordvest 


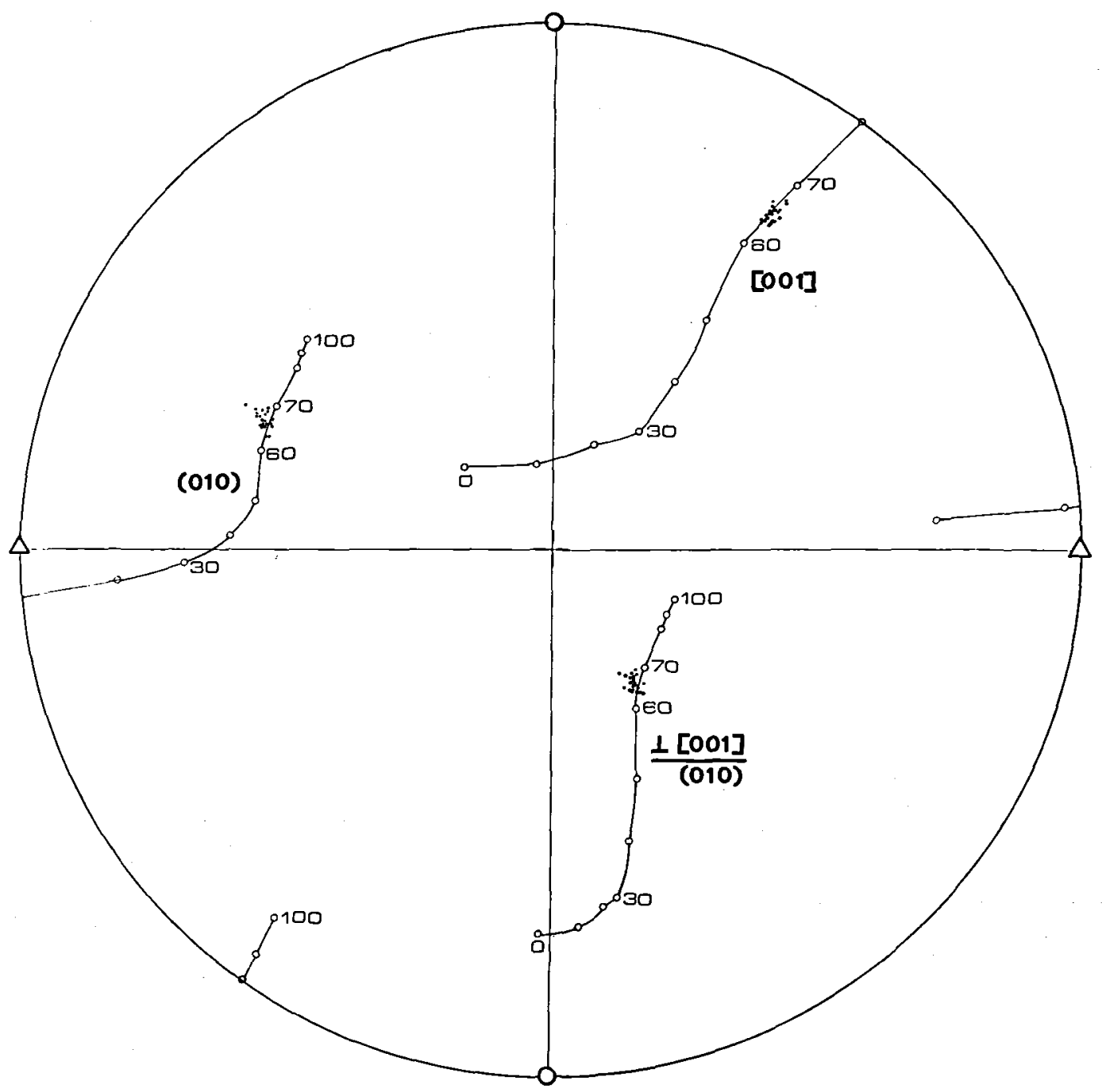

Fig. 1. Stereographic projection perpendicular to $[\mathrm{n} \beta]$ showing the migration curves of the twin axes of the Albite, Carlsbad and Albite-Carlsbad laws and the position of the 22 labradorites listed in Table 1. These occupy the narrow field between An 63 and 69 . High curves after Burri, Parker \& Wenk 1967. An 100 is corrected after Wenk and Trommsdorff 1967. Triangles $=[\mathrm{n} \gamma]$, circles $=[\mathrm{n} \alpha]$.

Fjord. These dolerite dikes belong to the Upper Cretaceous and Lower Tertiary Brito-Arctic province and are regarded as feeders of the flood basalts. In Charcot Land, the dolerites had been noted in 1934 by the Backlund party (Backlund 1955). The sketch map by Haller (1971, Fig. 120) indicates their distribution. Our study on erratics of basaltic composition shows that porphyritic flood basalts as well as dolerites must be present at the base of the ice cap, within reach of the Daugaard-Jensen Gletscher - a continuation in direction of the Tertiary basalts on the West Coast of Greenland.
In addition to the aforementioned basalt erratics, blocks of the enigmatic Scolithus quartzite and two types of psephitic rocks are also present. One is genuine, unsorted, nonstratified, consolidated tillite with components of quartzite, gneiss, granite, marble, carbonate-chlorite-schist and slate, together with angular fragments of fresh microcline, albite, quartz, brown biotite, green amphibole, garnet, pyroxene, chlorite, sericite and ore in a finegrained, carbonate-bearing argillaceous matrix (Eo-Cambrian?). The second type of psephite is a slaty conglomerate with planar and linear textures. While components of 
a

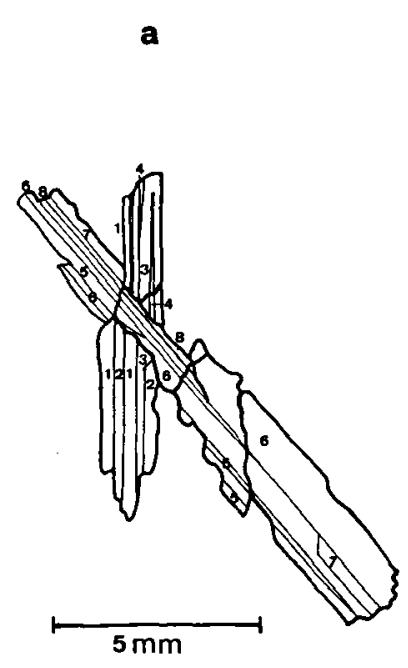

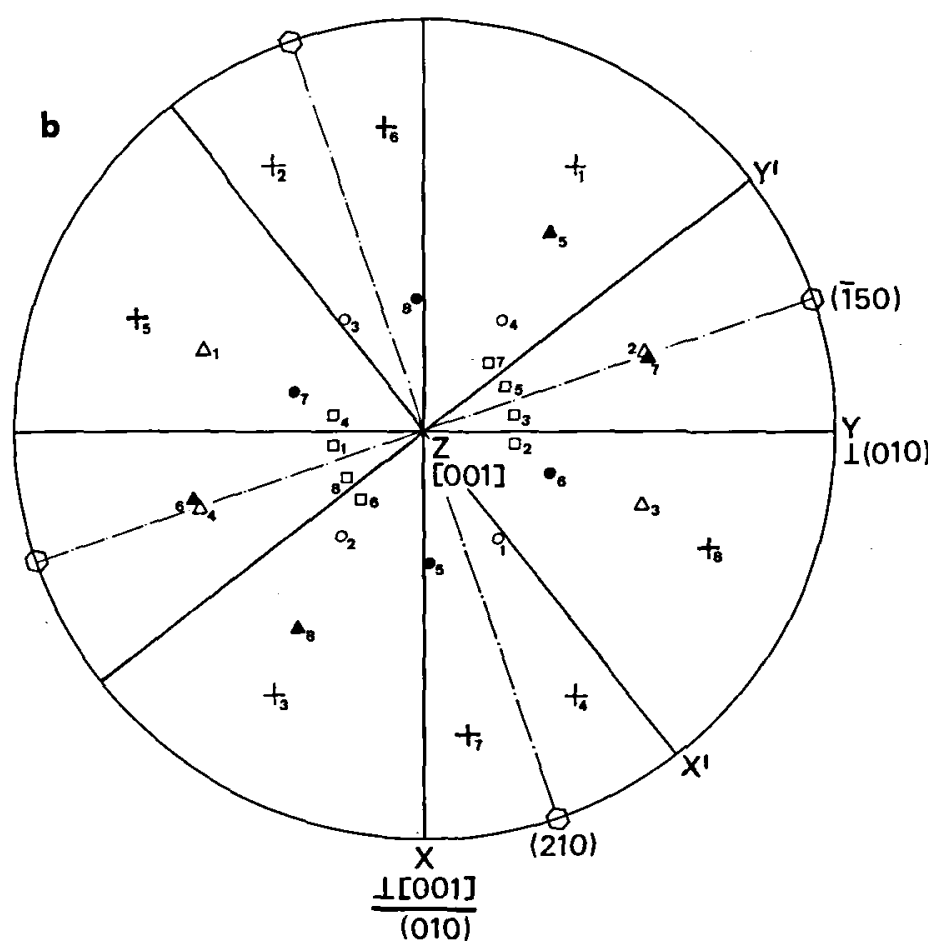

Fig. 2.

a: Drawing of two interpenetrating (010) fourlings of labradorite in porphyritic basalt from the southern moraine of Daugaard-Jensen Gletscher, Scoresby Sund (sample Daug 12). The mean values of the optic orientation of the eight individuals are expressed by Euler angles $\Phi 54^{\circ}, \Theta 36^{\circ}, \Psi 29.5^{\circ}, 2 \mathrm{~V} \gamma 77^{\circ}$, corresponding to An 64-65.

b: Stereographic projection perpendicular to [001] showing the position of the chief directions (circles $=n \alpha$, crosses $=n \beta$, triangles $=$ ny, squares = optic axes B) of the eight individuals of the intergrowth. The indicatrices of the fourlings 1 to 4 and 5 to 8 both show the symmetry mmm. Both fourlings have the Carlsbad axis [001] $=Z$ in common. The Albite twin axes $(010)=Y$ and $Y^{\prime}$ and the AlbiteCarlsbad axes $\perp[001] /(010)=\mathrm{X}$ and $\mathrm{X}^{\prime}$ form an angle of $38^{\circ} \pm 1^{\circ}$ (minor cracks slightly displace the phenocryst). Two perpendicular symmetry planes between the interpenetrating fourlings intersect in [001] and can be interpreted as (150) resp. (150) and (210) resp. (210) (also (740) gives a close fit). These symmetry planes bring the rectangular coordinate axes $Z=[001], Y=\perp[001] /(010)$ of one fourling into the position of those of the second fourling $Z^{\prime} Y^{\prime} X^{\prime}$. The same reflection brings the vibration directions $n \alpha, n \beta, n \gamma$ of each individual of the first fourling into the position of corresponding indicatrix axes of an individual of the second fourling: $1 / 8,2 / 7$, $3 / 5,4 / 6$ and $1 / 5,2 / 6,3 / 8,4 / 7$.

granite and gneiss are absent, quartzite, finegrained greenschist, slate and marble are common. Neither feldspars, nor ferromagnesian silicates are seen in thin-section. The brown matrix consists of iron-ore, quartz, calcite and sericite. The texture resembles the tilloid described by Steck (1971) from Charcot Land, but the components are quite different.

The rocks described were collected in 1957 by the first author, who was a member of the Danish Expeditions to East Greenland 1947-58 directed by Dr. Lauge Koch. We are obliged to Dr. Niels Henriksen, København, for valuable geological information, and to Dr. R. Vocke, Basel and Dr. H. R. Wenk, Berkeley for critical reading of the manuscript.

\section{Dansk sammendrag}

Strøkorn af labradorit fra moræeneblokke af basalt er blevet undersøgt med universal drejebord. Labradoriten har gennemvoksnings firlinger bestående af to sat tvillinger efter $(010)$ med frelles c-axe. I nogle firlinger danner (010) planerne i de to sæt en vinkel på $38^{\circ} \pm 1^{\circ}$, og to på hinanden vinkelrette tvillingplaner er mulige. I et andet tilfælde er vinklen $52^{\circ}$, men c-axen er stadigt den karakteristiske falles retning.

De undersøgte blokke viser at der findes basalt i DaugaardJensen gletscherens afstrømningsomrảde i $\emptyset$ st-grønland, 150 $\mathrm{km}$ nord for den nordligste, kendte forekomst af den brito-arctiske plateau-basalt provins.

\section{References}

Backlund, H. G. 1955. Report by H. G. Backlund in 'Report on the expeditions to central East Greenland 1925-1939 
conducted by Lauge Koch, Part II. Meddelelser om Grønland, 143, 2.

Barth, T. F. W. 1969. Feldspars. Wiley-Interscience, New York.

Burri, C. 1963. Bemerkungen zur sogenannten "Banater Verwachsung" der Plagioklase. Schweiz. Mineral. Petrogr. Mitt. 43, 71-80.

Burri, C., Parker, R. L., Wenk, E. 1967. Die optische Orientierung der Plagioklase. Birkhäuser Verlag, Basel.

Geological Map of Greenland 1:500000, Sheet 12, Scoresby Sund, 1984.

Haller, J. 1971. Geology of the East Greenland Caledonides. Interscience Publ. London.

Steck, A. 1971. Kaledonische Metamorphose der praekambrischen Charcot Land Serie, Scoresby Sund, Ost-Grönland. Meddelelser om Grønland, 192, 3.
Streckeisen, A. 1932. Junge Eruptivgesteine im östlichen Banat mit besonderer Berücksichtigung ihrer Feldspäte. Bul. Soc. rom. Geol. 1, 18-56.

Wenk, E. 1961. On the crystalline basement and the basal part of the Pre-Cambrian Eleonore Bay Group in the southwestern part of Scoresby Sund. Meddelelser om Grønland, $168,1$.

Wenk, E. 1961. Tertiary of Greenland, in Geology of the Arctic, Toronto, p. 278-284.

Wenk, E., Grütter, O., Schwander, H. 1961. Labradorit aus Plateaubasalt von Ostgrönland. Schweiz. Mineral. Petrogr. Mitt. 41, 53-63.

Wenk, E., Schwander, H., Wenk, H. R. 1965. Labradorit von Surtsey. Acta. Nat. Islandica, 2, 5, 1-29. 